Ulu Aslan, E. ve Baş, B. (2022). Eğlence amacına duyarlı medya okuryazarlığı ölçeğinin geliştirilmesi. Ana Dili Eğitimi Dergisi, 10(1), 74-88.

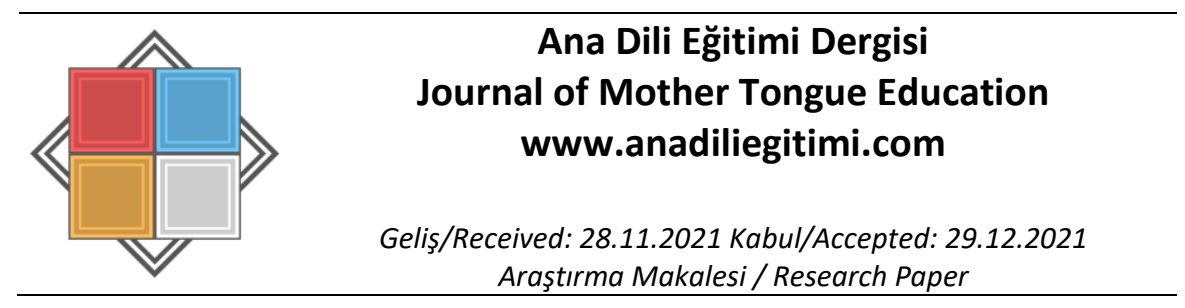

\title{
Eğlence Amacına Duyarlı Medya Okuryazarlığı Ölçeğinin Geliştirilmesi*
}

\author{
Emine ULU ASLAN** \\ Bayram $B A S^{* * *}$
}

\begin{abstract}
Öz
Bu çalışmanın amacı, ortaokul öğrencilerinin eğlence amaçlı takip ettiği medya araçlarına yönelik bir medya okuryazarlığı ölçeği geliştirmektir. Araştırmada analizler öncesi, literatür taraması, öğretmen ve öğrencilerle görüşmeler, madde havuzu oluşturma, uzman görüşü alma, ön deneme ve uygulama olmak üzere ölçek geliştirme aşamaları takip edilmiştir. Ölçeğin açımlayıcı faktör analizi (AFA) farklı illere bağlı resmi ortaokullarda öğrenim gören 404 7.sınıf öğrencisine uygulanan ölçek formları üzerinde gerçekleştirilmiştir. Bu analizde, 24 maddelik ölçeğin KMO değerinin .935 ve Barlett testinin $\chi 2=5048,392$ ( $p \leq .01$ ) olarak sonuçlanması verilerin AFA için uygun olduğunu kanıtlamıştır. AFA sonucunda ölçeğin tek boyutlu yapıda olduğu ve bu boyutun toplam varyansın \%43'ünü açıkladığı tespit edilmiştir. Tek boyutlu yapıyı doğrulamak için doğrulayıcı faktör analizi (DFA) ilk örneklem grubundan farklı 234 ortaokul öğrencisine uygulanan ölçek formları üzerinde yapılmıştır. DFA sonucunda ölçeğin tek boyutlu yapısının doğrulandığı ve uyum indekslerinin karşılaması gereken değerleri sağladığı belirlenmiştir (RMSEA=,078, GFI=,90, CFI=,93, NFI=,91). Bulunan değerler doğrultusunda ölçeğin geçerli ve güvenilir olduğu sonucuna ulaşılmıştır.
\end{abstract}

Anahtar Kelimeler: Medya okuryazarlığı, eğlence amaçlı medya, ölçek geliştirme

\section{Developing a Media Literacy Scale Sensitive to Entertainment Purpose}

\begin{abstract}
The aim of this study is to develop a media literacy scale for the media tools that secondary school students follow for entertainment purposes. Before the analysis in the research, the stages of scale development including literature review, interviews with teachers and students, creating an item pool, getting expert opinion, and pre-testing were followed. The exploratory factor analysis (EFA) of the scale was carried out on the scale forms applied to 404 7th grade students studying at public secondary schools in different provinces. In this analysis, the KMO value of the 24 -item scale was .935 and the Barlett test $\chi 2=5048.392(p \leq .01)$, proving that the sample group size was excellent, and the data were suitable for EFA. As a result of EFA, it was determined that the scale was in a one-dimensional structure and this dimension explained $43 \%$ of the total variance. To confirm the one-dimensional structure, confirmatory factor analysis (CFA) was performed on the scale forms applied to 234 secondary school students different from the first sample group. As a result of CFA, it was confirmed that the one-dimensional structure of the scale was confirmed and the fit indexes provided acceptable values (RMSEA=.078, GFI=.90, $\mathrm{CFI}=.93, \mathrm{NFI}=.91$ ). In line with the values found, it was concluded that the scale is valid and reliable.
\end{abstract}

Keywords: Media literacy, entertainment media, scale development

\footnotetext{
* Bu çalışma, Prof. Dr. Bayram BAŞ danışmanlığında, Yıldız Teknik Üniversitesi Türkçe Eğitimi Ana Bilim Dalı’nda yürütülen "Çocuk Medyasında Dönüştürülen Masalların Eleştirel Düşünme ve Medya Okuryazarlığı Becerilerine Etkisi" başlıklı doktora tezinden üretilmiştir.

** Arş. Gör., Muş Alparslan Üniversitesi, Eğitim Fakültesi, Türkçe Eğitimi Anabilim Dalı, Muş, e.ulu@alparslan.edu.tr, ORCID: orcid.org/ 0000-0003-3569-9395.

*** Prof. Dr., Yıldız Teknik Üniversitesi, Eğitim Fakültesi, Türkçe Eğitimi Anabilim Dalı, İstanbul, bayrambas@gmail.com, ORCID: orcid.org/ 0000-0003-3569-9395.
} 


\section{Giriş}

21. yüzyılın okuryazarlık eğilimleri, teknolojinin gelişmesi ile medya okuryazarlığı ve dijital okuryazarlık gibi alanlara doğru kaymaktadır. Bilim ve teknolojideki hızlı değişimler, insanların bilimselteknolojik gelişmelere, sosyal entegrasyona, etkileşime uyum sağlayabilmeleri ve eğitim sistemlerini de bu doğrultuda planlamaları gerektiğini göstermektedir. Yeni dünya, öncekinden daha görsel ve yeni anlam kodları için daha fazla bilişsel beceri gerektirecek şekilde güçlenerek gelişimini sürdürmektedir. Bu sebeple dijital evrenin yeni iletişim kodları, medya okuryazarlığı becerilerini geliştirmeyi, eleştirel düşünme sürecini öğrenmenin her aşamasında gerçekleştirebilmeyi ve bunları yaşamla okul arasında etkileşim kurarak kullanabilmeyi gerektirir.

Küreselleşme olarak tanımlanan medyanın yol açtığı zaman ve mekânın yeniden düzenlenmesi durumu modern dünyayı dönüştürmüş ve halen dönüştürmekte olan daha geniş süreçlerin bir parçasıdır. Medya okuryazarlığı terimi bu sebeple literatürde farklı şekillerde kullanııı ve kesin sınırları yoktur. Fakat en genel tanımların temelinde, dünyanın farklı bölgelerinin birbirlerine olan bağımlılı̆ına ve etkileşimin karmaşık biçimlerine yol açan bir sürece gönderme yapılmaktadır (Thompson 2008: 227). Medya okuryazarlığı tanımları, medya mesajlarını anlama, analiz etme ve değerlendirme; medya mesajları oluşturma, katılma ve yansıtma becerileri üzerinde şekillenir (Baker 2010; Hobbs 2013; Thoman 1995). Benzer şekilde medya okuryazarlığının medyaya ait bir bilgi, eğlence, zenginleştirme, büyüme, güçlendirme ve iletişim kaynağının kullanımı ve bu kaynaklara ilişkin gerekli yetkinliklerin kazanımı yönünde tanımları da mevcuttur (Wan ve Gut 2008: 179). "Medya eğitimi", "eleştirel medya okuryazarlığı", "medya okuryazarlı̆ı" terimleri, insanların teknolojinin gelişimi ile birlikte popüler kültür, dijital medya ve bunların şekillendirdiği kültür hakkında kazanmaları gereken yeterlilikleri tanımlamak için kullanılan pek çok terimden yalnızca birkaçıdır. Günümüzde aktivistlerin, akademisyenlerin, kütüphanecilerin, iş liderlerinin, hükûmet yetkilileri ve yaratıcı medya profesyonellerinin kullandıkları "yeni okuryazarlıklar", "gençlik medyası", "bağlantılı öğrenme”, "dijital medya ve öğrenme", "dijital vatandaşık" terimleri "medya eğitimi" topluluğunun bir parçasıdır (Hobbs 2018: 6). Hepsi belirli becerileri amaçlar, bazı anahtar sorulara cevap arar ve karakteristik temel bileşenlerden oluşur.

Öğrenmenin özellikle çağımızda her yerde, günün her anında ve her şekilde gerçekleştiği göz önüne alındığında bugünün dünyasında öğrendiklerimizin ve nasıl öğrendiğimizin kaynaklarında ve içeriğinde büyük bir değişikliğe neden olan medya ile eğitim, eğlence ve öğrenme arasındaki yakınsamadır (Thoman ve Jolls 2004: 21). Yakınsama ile birden fazla medya platformu arasındaki içerik akışı, birden fazla medya endüstrisi arasındaki iş birliği ve istedikleri eğlence deneyimlerini aramak için neredeyse her yere gidecek olan medya izleyicilerinin göç davranışları kastedilmektedir (Jenkins 2006: 2). Bu bağlamda her türlü içeriğin ait oldukları ya da kapsadıkları alanlar da birbirlerine yakınlaşma eğilimi gösterir. Bu sebeple medya okuryazarlığı gelecekten daha çok bugünle ilgilidir ve eğitimin odak noktasında olmalıdır. Özellikle eğitim çerçevesinde düşünüldüğünde uygulamalar ve araştırmacılar sonucu, sınıf içinde ve dışında kullanılan medya içeriklerine karşı dikkate alınması gereken belirli unsurları Hobbs şu şekilde maddeler (1998: 266):

- Hem yazılı hem de görsel medyadaki temsillerin yapılandırılmış doğası hakkında farkındalık;

- Medya mesajlarının belirli amaç ve hedeflere sahip birkaç farklı kurum tarafından üretildiği ekonomik ve politik bağlam hakkında bilgi;

- İzleyicilerin mesajlardan anlam inşa etme yolları ve mesajları çeşitli biçimlerde seçme, yorumlama ve kullanma süreçlerinin çeşitliliği hakkında farkındalık ve bilgi.

Bu unsurlar literatürdeki diğer araştırmacıların saptadığı medya okuryazarlı̆̆ına ilişkin gerçekleştirilen aşamalarla benzerlik göstermekle birlikte içeriği analiz etmenin yanında bunun nasıl yapılacağı bilgisi ve farkındalığının da önemini vurgulamaktadır. Çünkü okuduğumuz gazetelerden kullandığımız ders kitaplarına, haber bültenlerimizdeki fotoğraf ve video görüntülerine kadar tüm medya mesajları birer yapıdır ve üreticilerinin kendi değerleri, fikirleri ve savunmaları vardır. Analizin, değerlendirmenin ve sorgulamanın nasıl yapılacağı bilgisi bu yapıların üretim sürecinin de anahtarını verir. İzleyicilerin medyada anlam konusunda nasıl pazarlık ettiklerini anlamak, okuyucuyu "yazarlığın ikiz otoriteleri ve metnin kendisine" tabi kılan geleneksel mesaj analizi modellerinden uzaklaşan edebiyat eleştirisine dayanmaktadır (Hobbs 1998a: 269). Eğlence amaçlı medya içeriklerinin bu tür 
eleştirel okuryazarlık sürecine dâhil edilmesi ve gerçekleşen öğrenme deneyimi, geleneksel eğitimin "metin öğretimi" yaklaşımında olduğu gibi öğrencilere içeriğin bilgisini doğrudan ezberlemek yerine metni araç olarak görüp onun biçimini de düşünmeye teşvik eden bir tartışma ortamını beraberinde getirir. Bunu gerçekleştirirken öğrenci metinle olan ilişkisini değiştirerek, onu olduğu gibi tüketmek ve alımlamak yerine kendisini aktif bir fikir işleyicisi konumuna yerleştirir. Ayrıca, popüler filmler, çizgi filmler, animasyonlar, reklamlar gibi medya metinleri öğrencilerin muhakemeye dayalı eleştirel düşünmelerini veya iletişim rahatsızlıklarını güçlendirmek için kullanıldığında, öğretmenler de medya okuryazarlığı pratiğine dahil olurlar (Hobbs 1998b: 49). Medyaya doymuş bir toplumda, okuryazarlık amacının, gençlere bilgi ve eğlenceyi değerlendirmek için gerekli olan eleştirel ve analitik beceriler kazandırarak onları yaşamlarını etkili bir şekilde yönetmeye hazırlamak olduğu düşünüldüğünde, bunun eğitiminin nasıl olacağı sorusunun cevabı elbette sınıf ortamında popüler kültür ve medya kullanımı ayrıca sınıf dışı etkinliklerde yüzleştikleri medya araçlarına karşı bir farkındalık geliştirmek olacaktır.

Medyanın olayların, anlatıların ve durumların bağlamlarını zaman ve mekânda değişimlerle aktarması, izleyicilerin belirli geleneksel, ideolojik ve söylemsel iletişim modlarının alıcıları olarak konumlanması, medya aracilığı ile anlam üretme sürecini deneyimlemeyi ve bu sürecin nasıl gerçekleştiğini anlamayı gerekli kılar. Medya içeriklerinin sınıf içi uygulamalarda kullanılması bu sürecin doğru yönetilmesi için çözüm yollarından biri olabilmektedir. Öğrencilerin önemli miktarda zaman alan kademeli bir süreç vasıtasıyla medya iletilerinin tipik özelliklerini tanımaya ve anlamaya başlaması, bu içeriklerin eleştirel düşünme ve medya okuryazarlığı üzerindeki etkisinin göstergesidir (Meibauer 2013: 39).

Medya ile başa çıkmak adına medya okuryazarlığı için birçok beceri tanımlansa da insanlar büyük miktarda bilgiyi işlemelerine izin veren rutinlere alıştıkça, günlük yaşamlarının neredeyse her saatinde film, video, dizi, reklam, sosyal medya gibi medya içerikleriyle karşılaştıkça, medyanın birey üzerindeki etkisi muazzam dereceye ulaşır. Bununla birlikte tüm medya üreticileri kendi izleyici kitleleri için mesajlarını iletebilecekleri teknikleri göz önünde bulundururlar. Ancak insanlar medyayı kendi amaçları için kullanırlar ve genellikle aşina oldukları için normal hale gelen tekrarlayan görüntülerin ve fikirlerin ikna edici doğası hakkında eleştirel düşünmezler (Gaines 2010: 15). Oysa medya aracılığı ile gerçekleştirilen "temsil” i gerçek olarak kabul etme alışkanlığını kırmak için eleştirel düşünmeyi içeriğe uygulamamı gerekir. Tüm medya araçlarının odak noktası iletişimin semiyotik doğasıdır. Bu sebeple medyadaki işaretler, okuyucunun/izleyicinin onu nerede ve ne zaman aldığının yanında, bir amaçtan kaynaklanan nesnelere, olaylara ve fikirlere yapılan göndermeleri de ifade eder. Yaşamın doğal akışında dahi kültürümüzün, dilimizin, yaşam geleneklerimizin kendine özgü işaretlerini yorumlar ve davranışlarımızı buna göre şekillendiririz. Gözlemlenebilir ya da varsayılabilir işaretlerin neler olduğu ya da hangi anlamları temsil ettiği gibi sorular sormak ve cevaplamak tek başına yeterli değildir. Medyada yineleme ve eleştirel düşünme, sürekli bir bilgi akışıyla başa çıkma stratejileri olarak öğrenilen davranışları anlama ve değiştirme alışkanlıklarını kırmak için beceri, farkındalık ve motivasyon gerektirir (Gains 2010: 25). Medya okuryazarlığı bu sebeple bizi değişen medya ve iletişim teknolojilerine uyum sağlamaya ve zihnimizi medyanın yeni işaretleri ve mesajları için açmaya teşvik eder. Kendimizi daha geniş bir mesaj çeşitliliğine açarak ve ardından bu mesajları yeni unsurlar için analiz ederek ve bu unsurları diğerlerinin anlaşılabilmesi için değerlendirerek medyaya karşı aktif bir konum elde ederiz.

\section{Araştırmanın Modeli}

\section{Yöntem}

Bu araştırmada ortaokul öğrencilerinin günlük yaşamlarında takip ettiği, çokça vakit harcadığı ya da maruz kaldığı eğlence amaçlı medya araçlarına yönelik eleştirel düşünmeyi de hedef alan bir ölçek geliştirmek amaçlanmıştır. Bu ölçeğin geliştirilme ihtiyacı, alan yazındaki mevcut ölçeklerin sınırlandırılmış bu amaca yönelik olmamasından ve uygulamadaki hedef kitleyi karşılamamasından doğmuştur. Bu kapsamda geliştirilen ölçek beşli likert yapısına uygun olarak oluşturulmuştur. Ölçekte yer alan maddeler "1= Kesinlikle Katılmıyorum, 2=Katılmıyorum, 3= Kararsızım, 4=Katılıyorum,

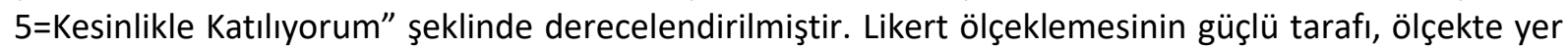
alan her bir önermenin, bir yandan ölçülmek istenilen içsel özelliğin ortaya çıkışına/belirlenmesine tek 
tek katkıda bulunurken (yani ölçülmek istenilen içsel özelliğin bileşenleri olarak içsel özelliğin belirlenmesine katkı sağlamakta) diğer taraftan ölçülmek istenilen içsel özelliğe ilişkin bir toplam puan elde edilmesine de imkân sağlıyor olmasıdır (Bayat 2014: 15).

\section{Araştırma grubu}

24 maddelik eğlence amacına duyarlı medya okuryazarlığı ölçeği Türkiye' nin farklı illerinde Millî Eğitim Bakanlığına bağlı ortaokullarda öğrenim gören 425 7.sınıf öğrencisine uygulanmıştır. 21 adet ölçek formunun boş bırakıldığı, hatalı ya da eksik doldurulduğu tespit edilmiş bunlar değerlendirmeye alınmamış olup sonrasında 404 adet geçerli ölçek formu üzerinde ölçeğe ilişkin geçerlilik ve güvenirlik çalışmaları yapılmıştır. Açımlayıcı faktör analizi için gerekli katılımcı sayısını tahmin etme yönergeleri şu noktalara odaklanır (Watkins 2021: 34): (a) mutlak katılımcı sayısı, (b) katılımcıların ölçülen değişkenlere oranı, (c) ölçülen değişkenlerin kalitesi ve (d) ölçülen değişkenlerin oranı. İlk durumda, Comrey ve Lee (1992'den aktaran Watkins 2021: 34) 100 katılımcının zayıf, 200'ün orta, 300'ün iyi, 500 'ün çok iyi ve 1.000 veya daha fazlasının mükemmel olduğunu öne sürmüşlerdir. Katılımcının değişkene oranı ile ilgili olarak, katılımcıların ölçülen değişkenlere oranını 5:1, 10:1 veya 20:1 olarak öneren çalışmalar mevcuttur (Benson ve Nasser 1998; Child, 2006). Bu görüşler doğrultusunda 24 maddelik bir ölçek için 404 kişilik bir çalışma grubu uygun görülmektedir. Ölçek geliştirme çalışma grubuna ilişkin veriler Tablo 1'de sunulmuştur:

Tablo 1.

AFA Çalışma Grubuna ilişkin Bilgiler

\begin{tabular}{lrrrr}
\hline II & Kız & Erkek & Toplam & $\%$ \\
\hline Bursa & 34 & 30 & 64 & 15,84 \\
\hline İstanbul & 64 & 52 & 116 & 28,72 \\
\hline Kocaeli & 25 & 22 & 47 & 11,63 \\
\hline Manisa & 15 & 20 & 35 & 8,66 \\
\hline Mardin & 26 & 22 & 48 & 11,88 \\
\hline Muş & 49 & 45 & 94 & 23,27 \\
\hline Toplam & 213 & 191 & 404 & 100 \\
\hline
\end{tabular}

Tablo 1'de görüldüğü üzere uygulama grubundaki 404 öğrenciden $\% 52,72$ 'ü kız $\% 47,28$ 'si erkektir. Açımlayıcı faktör analizinden farklı olarak doğrulayıcı faktör analizi için farkıı bir örneklem grubuna uygulama yapılmış, bu grubun sayısının ölçeğin toplam madde sayısının on katını karşılamasına dikkat edilmiştir. 243 kişi ile gerçekleştirilen uygulama sonrasında 234 geçerli ölçek formuna ulaşıımış bu formlar üzerinde doğrulayıcı faktör analizi yapılmıştır. DFA uygulama grubuna ilişkin bilgiler aşağıda sunulmuştur (Tablo 2):

Tablo 1.

DFA Çalışma Grubuna ilişkin Bilgiler

\begin{tabular}{lrrrr}
\hline II & Kız & Erkek & Toplam & $\%$ \\
\hline İstanbul & 72 & 64 & 136 & 58,12 \\
\hline Muş & 52 & 46 & 98 & 41,88 \\
\hline Toplam & 124 & 110 & 234 & 100 \\
\hline
\end{tabular}

Tablo 2'ye bakıldığında 234 kişilik uygulama grubunun \%53'ünü kız öğrenciler \%47'sini ise erkek öğrenciler oluşturmaktadır.

\section{Ölçek Geliştirme Süreci}

Literatür taraması ve madde havuzu oluşturma

Ölçek geliştirme çalışmasının ilk adımı olarak konu ile ilgili literatür incelenmiştir (Bazalgette 2012; Buckingham 2003; Diergarten, Möckel, Nieding ve Ohler 2017; Facione 1990; Freire 1998; Giroux 
1991; Hobbs 2005, 2013 2018; Jolls ve Thoman 2008; Kellner ve Share 2005; Stuckey 2007; Thoman 1995; Thoman ve Jolls 2004; Whitley 2013). Ayrıca ölçeğin içerik ve kapsamını belirlemek amacıyla öğretmen ve öğrencilerle yapılan görüşmelerden yararlanılmıştır. Literatür taramasında, ölçek konusu için hangi soruların/konuların değerlendirilmesi gerektiğine dikkat edilmiştir (DeVellis 2003'ten aktaran Karakoç ve Dönmez 2014: 41).

Madde havuzunun oluşturulması yapıya uygun durum-bağlam-ortam belirlendikten sonra, bunlara uygun davranışsal göstergeler belirlenmesiyle başlar, önceki kavramsal çerçeve ve içeriğe uygun bir madde formatının seçilmesi-belirlenmesiyle devam eder (Erkuş 2007: 18). Bu doğrultuda üretilen maddelerin kuramsal yapı ile onun üzerinde şekillenen ve ölçmesi amaçlanan davranışsal göstergelere uygun olması gerekir. Eğlence amacına duyarlı medya okuryazarlığı ölçeğinin kuramsal yapıyı kapsaması ayrıca medya okuryazarlığı becerilerinin en çok ilgilendiği eleştirel okuryazarlık boyutunu temel alması amaçlanmıştır. Üretilen maddeler tasarlanırken hedef kitleye uygunluk ilkesi gözetilmiş, maddelerin anlaşılır olmasına, birden fazla yargı ve düşünce ifadesi belirtmemesine özen gösterilmiştir. llk aşama sonunda toplam 33 maddeden oluşan bir ölçek taslağı hazırlanmıştır.

\section{Kapsam ve Görünüm Geçerliği İçin Uzman Görüşü Alma}

Ölçeğin kapsam, görünüm ve dil geçerliliğini sağlamak için ölçek maddelerinin değerlendirilmesi amacıyla "kullanılmalı", "düzeltilmeli/değiştirilmeli", "çıkarılmalı" seçeneklerinden ve açıklamalar kısmından oluşan bir ölçek uzman görüşü formu hazırlanmıştır. Ayrıca formun sonunda ölçekte yer alması gerektiği düşünülen maddelerin sorulduğu bir kısım bırakılmıştır. Form, Millî Eğitim Bakanlığı'na bağıı ortaokullarda görev yapan yüksek lisansını tamamlamış iki Türkçe öğretmeni, ölçme değerlendirme alanında görev yapan bir öğretim üyesi, farklı illere bağı üniversitelerde Türkçe Eğitimi ana bilim dalında görev yapan dört öğretim üyesi ve iki araştırma görevlisi olmak üzere toplam 10 uzmana gönderilmiştir. Kapsam geçerliği için en az 5 en fazla 40 uzman görüşüne ihtiyaç duyulan Lawshe (1975: 567) tekniği kullanılmıştır. Lawshe tekniğinde kapsam geçerliği oranı; her bir maddeye "kullanılmalı/gerekli" diyen uzman sayısının toplam uzman sayısına bölümünün bir eksiği ile formüle edilir:

$$
\mathrm{KGO}=\frac{\mathrm{N}_{\mathrm{G}}}{\mathrm{N} / 2}-1
$$

Kapsam geçerlik oranı başlangıç olarak 5 uzman için minimum 0,99 iken uzman sayısı artıkça düşmektedir. Bu oran 10 uzman görüşü için 0,62 olarak belirlenmiştir (Lawshe 1975: 568). Maddelerin gerekliliğinin, açıklığının ve özgüllüğünün değerlendirildiği bu aşamada bazı ifadelerin çıkarılması ve değiştirilmesi önerilmiştir. Bu doğrultuda ölçekten 0,62'nin altında kalan 9 madde çıkarılmış kalan 24 maddeden 7'si üzerinde gerekli değişiklikler yapılmıştır.

Bu aşamanın sonunda pilot uygulama için 24 maddelik 5'li likert tipi bir ölçek elde edilmiştir. Uygulamadan önce ölçeğin son hali, anlaşılamayan ifadelerin olup olmadığını tespit etmek amacıyla, 7.sınıfta öğrenim gören 20 kişilik bir gruba ön deneme şeklinde uygulanmış, ölçek maddeleri gruba sesli bir şekilde okunmuş herhangi bir sorunla karşılaşılmamıştır.

\section{Verilerin Analizi}

Ölçeğin açımlayıcı faktör analizinde SPSS 26.0; doğrulayıcı faktör analizinde LiSREL 8.8 programlarından yararlanılmıştır. Ayrıca ölçeğin güvenirlik analizi için Cronbach Alfa katsayısına bakılmıştır.

\section{Açımlayıcı Faktör Analizine Yönelik Bulgular}

\section{Bulgular}

Uygulamadan elde edilen verilerin açımlayıı faktör analizine uygun olup olmadığını görmek için ilk olarak Kaiser-Meyer-Olkin (KMO) ve Barlett testi yapılmıştır. KMO değerinin 0.1'e yakın olması 
yüksek oranda uygunluk içerdiği anlamına gelir (Tablo 4). Elde edilen değerlerin tasnifi şu şekildedir: 0.50-0.60 arası kötü, $0.60-0.70$ arası zayıf, $0.70-0.80$ arası orta, $0.80-0.90$ arası iyi ve 0.90 üzeri için mükemmel olarak değerlendirilir (Çokluk, Şekercioğlu ve Büyüköztürk 2018: 207). Ölçeğin KMO değerleri Tablo 3'te gösterilmiştir.

Tablo 3.

Eğlence Amacına Duyarlı Medya Okuryazarlığı Ölçeğinin KMO ve Barlett Testi

\begin{tabular}{|c|c|c|}
\hline \multicolumn{3}{|l|}{ KMO and Bartlett's Test } \\
\hline \multicolumn{3}{|c|}{ Kaiser-Meyer-Olkin Measure of Sampling Adequacy. } \\
\hline Bartlett's Test of Sphericity & Approx.Chi-Square & 5048.392 \\
\hline & df & 276 \\
\hline & Sig. & .000 \\
\hline
\end{tabular}

Tablo 3'te belirtildiği üzere ölçeğin .935 KMO değerine ilişkin verilerin açımlayıcı faktör analizi için mükemmel derecede uyum gösterdiği görülür. Ayrıca ölçeğin toplam maddeleri için Cronbach's Alfa değeri 0.940 olduğundan verilerin güvenirliğinin oldukça yüksek olduğu söylenebilir. Eğer bu değer ,70 ve üzerinde bir değere sahip ise ölçeğin iç tutarlılığa sahip olduğu söylenebilir (Seçer 2015). Verilerin faktör analizine uygunluğu belirlendikten sonra faktör sayısının belirlenmesi için maddelerin özdeğer istatistiği, yamaç birikintisi grafiği ve faktörler bileşenlerinin toplam varyanstaki yüzdelik oranlarına bakılmıştır. Yamaç birikinti grafiği Şekil 1'de sunulmuştur.

Scree Plot

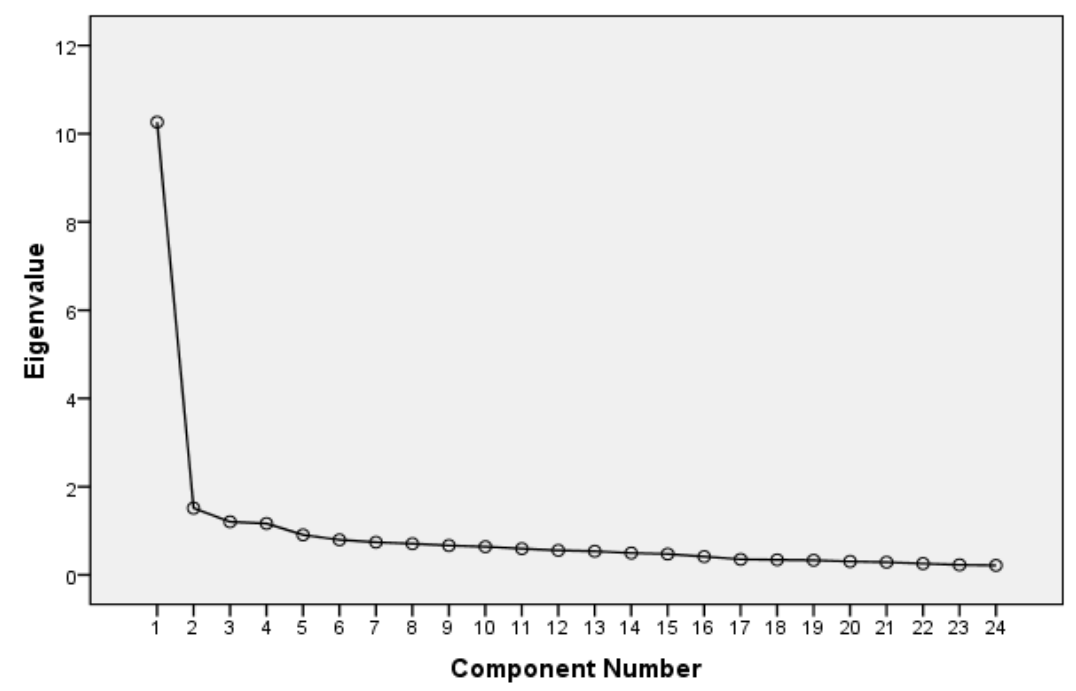

Şekil 1. Eğlence Amacına Duyarlı Medya Okuryazarlığı Ölçeğinin Faktör Sayısına İlişkin Yamaç Birikinti Grafiği

Yamaç birikinti grafiğinin dikey kııımdaki değerler özdeğerleri yatay eksendeki değerler ise faktör sayısını belirtir. Özdeğerler, grafik içinde daire (yıldız, kare vb) işaretleri olarak çizilir ve ardışık değerler bir çizgi ile bağlanır. Grafikteki iniş eğilimi, faktörlerin toplam varyansa olan katkıları doğrultusunda kırılmalarla gösterilir ve bir noktadan sonra grafiğin eğiminde önemli bir düşüş yaşanarak düz bir şekil alır (Koçak, Çokluk ve Kayri 2016: 336). Faktör çıkarımı, bir "dirsek" (kırıma) oluşturduğu noktada durdurulmalıdır (Thampson 2004: 33). Kırılmadan önceki bileşen sayısı faktör sayısını belirlemede yardımcı olur. Bu yönteme göre kırılma noktasından sonraki faktörlerin varyansa katkıları değerlendirmeye alınmayacak büyüklüktedir. Eğlence amacına duyarlı medya okuryazarlı̆ı ölçeğinin kırılma noktasının ikinci bileşene denk geldiği görülmektedir. Bu görüşler ışığında, şekil 1'de görüldüğü üzere kırılma noktasından önce bir bileşenin yer alması ölçeğin tek faktörlü yapıya sahip olduğunu gösterir. Fakat yamaç birikinti grafiği testi araştırmacılar tarafından faktör sayısının 
belirlenmesinde çoğu zaman öznel bir değerlendirme ile sonuçlanır (Watkins 2021: 133). Bunun sonucunda her araştırmacıya göre yamaç birikinti grafiği farklı yorumlanabilir. Bu belirsizliği ortadan kaldırmak adına özdeğeri 1'den büyük olan faktörler ve bunların ölçeğin toplam varyansını açıklamada ne kadarlık bir yüzdelik değere sahip olduğuna bakılır. Tablo 4'te bu değerlere ilişkin bilgilerin yer aldığı veriler gösterilmiştir.

Tablo 4.

AFA Sonucu Faktör Özdeğerleri ve Varyans Yüzdeleri

\begin{tabular}{lrrr}
\hline Faktörler & Özdeğerler & Açıklanan Varyans \% & Kümülatif Varyans \% \\
\hline 1 & 10.502 & 43.757 & 43.757 \\
\hline 2 & 1.529 & 5.006 & 49.068 \\
\hline 3 & 1.192 & 4.965 & 54.083 \\
\hline 4 & 1.146 & 4.774 & 58.941 \\
\hline
\end{tabular}

Tablo 4'te özdeğeri 1'in üzerinde 4 faktör belirlenmiştir. Birinci faktörün özdeğeri $10^{\prime}$ un üzerindedir ve toplam varyansın \%43'ünü açıklamaktadır. Diğer faktörlerin toplam varyansa katkılarının \%5 ve altında kalması ölçeğin tek faktörlü yapısını doğrulamaktadır. Sosyal bilimlerde ölçek maddelerinin, toplam varyansı \%40 ile \%60 arasında bir oranla açıklaması beklenmektedir (Can 2014). Bu bilgiye göre ölçeğin tek faktörlü yapısı tek başına toplam varyansın \%43'ünü açıklamaya yettiğinden diğer faktörlerin ölçekten çıkarılmasına karar verilmiştir. Maddelerin faktörlerle olan ilişkisini açıklayan yük değerleri Tablo 5'te sunulmuştur.

Tablo 5.

Faktör Yük Değerleri

\begin{tabular}{|c|c|c|c|c|}
\hline \multirow[t]{2}{*}{ Maddeler } & \multicolumn{4}{|c|}{ Faktör Yük değerleri } \\
\hline & 1.Faktör & 2.Faktör & 3.Faktör & 4.Faktör \\
\hline M1 & .771 & & & \\
\hline M2 & .746 & & & \\
\hline M3 & .741 & & & \\
\hline M4 & .732 & & & \\
\hline M5 & .716 & & & \\
\hline M6 & .713 & & & \\
\hline M7 & .713. & & & \\
\hline M8 & .706 & & & \\
\hline M9 & .704 & & & \\
\hline M10 & .699 & & & \\
\hline M11 & .670 & -.388 & & \\
\hline M12 & .658 & .324 & & \\
\hline M13 & .644 & & & \\
\hline M14 & .634 & & -.470 & .316 \\
\hline M15 & .628 & & & .343 \\
\hline M16 & .626 & & & .432 \\
\hline M17 & .623 & & & \\
\hline M18 & .611 & & -.473 & \\
\hline M19 & .597 & & & \\
\hline M20 & .587. & & & \\
\hline M21 & .568 & .398 & & \\
\hline M22 & .525 & & .376 & \\
\hline M23 & .501 & & & \\
\hline M24 & .467. & & & \\
\hline
\end{tabular}


Maddelerin yer aldıkları faktördeki yük değerlerinin faktör sayısını belirtmede karar verici olması için yüksek ve bütüncül bir yapıya sahip olması beklenir. Bu düzeydeki varyans dikkate çekicidir ve genel olarak, işaretine bakılmaksızın 0.60 ve üstü yük değeri yüksek; 0.30-0.59 arası yük değeri orta düzeyde büyüklükler olarak tanımlanabilir ve değişken çıkartmada dikkate alınır (Büyüköztürk 2002: 473; Watkins 2021). Tablo 6'da tek faktörlü yapıya ilişkin modelde maddelerin yük değerlerinin .450 'den yüksek olduğu görülür. Bu tek faktörlü yapıya dair ölçme derecesinin iyi olduğunu gösterir. Ayrıca diğer faktörlere dağılan maddelerin yük ve binişiklik değerlerine de bakılmıştır. Bir maddenin binişik olması birden fazla faktörde kabul düzeyinin yüksek yük değeri vermesidir ve maddenin iki ya da daha fazla faktörde sahip olduğu yük değerleri arasında farkın .1'den küçük olması demektir (Çokluk, Şekercioğlu ve Büyüköztürk 2018: 233; Seçer 2015). Bu veriler ışığında maddelerin tek faktörlü yapıyı ölçme derecesinin çok faktörlü yapıya göre daha yüksek olduğu ayrıca binişik madde olmadığı görülmüştür.

\section{Doğrulayıcı Faktör Analizine Yönelik Bulgular}

234 kişilik uygulama grubuna ilk yapılan doğrulayıcı faktör analizi sonuçlarında RMSEA değeri iyi uyum değerinden yüksek çıkmış (0.92), modelin daha iyi bir uyum göstermesi için programın düzeltme indislerindeki öneriler dikkate alınmıştır. Öngörülen düzeltmeler sonucu, en yüksek değeri veren madde 1 ve madde 2 arasında gerekli modifikasyon yapılmıştır. Böylece modelin hatalarını düzeltmeye ilişkin öneriler modele eklenerek model yeniden test edilmiştir. Yapılan analiz sonucu ölçeğin daha iyi uyum gösteren bir yapıya ulaştığı söylenebilir. Şekil 2'de test edilen tek faktörlü yapıya ilişkin doğrulayıcı faktör analizi sonuçları gösterilmiştir.

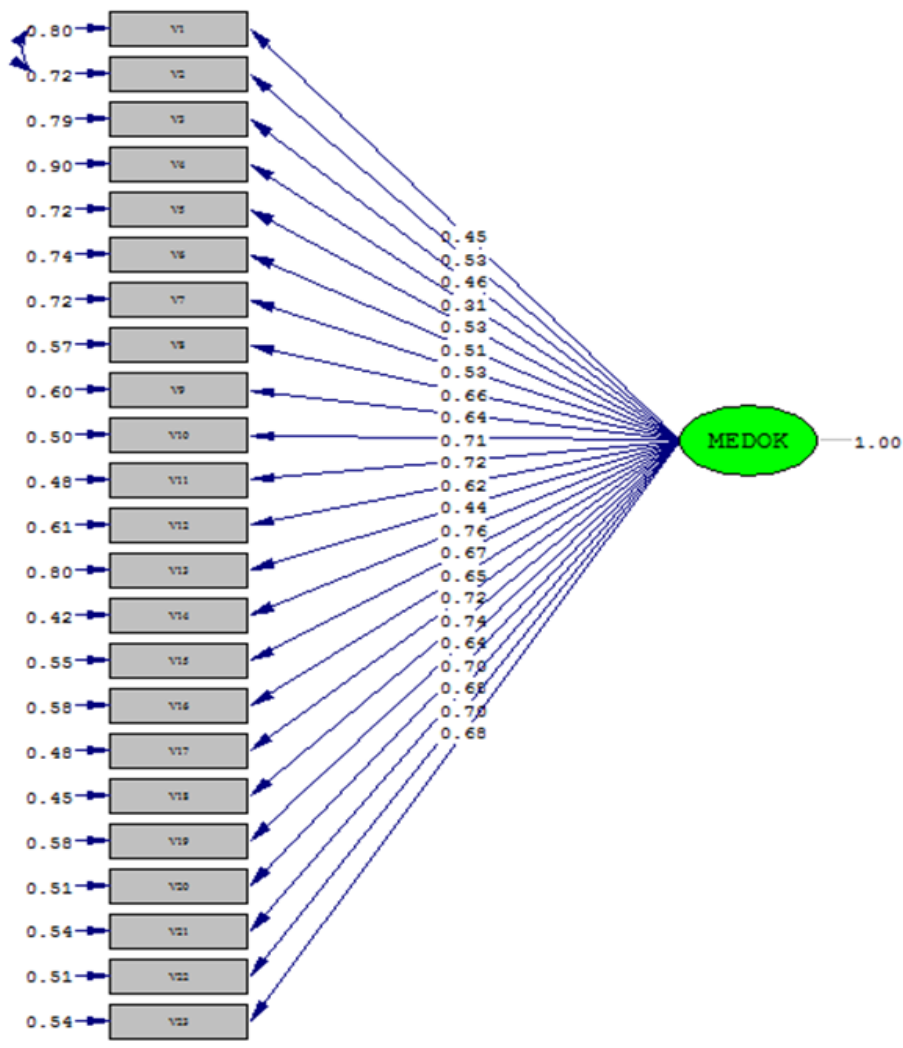

Şekil 2. Eğlence Amacına Duyarlı Medya Okuryazarlığı Ölçeğinin DFA Diyagramı

Şekil 2'de görüldüğü üzere madde yük değerleri 0,31 ile 0,76 arasında değişmektedir. Çıkması beklenen ile var olan arasındaki değerin anlamlılığı hakkında bilgi sunan $p$ değerinin doğrulayıc faktör analizi için anlamlı olması beklenir (Çokluk, Şekercioğlu ve Büyüköztürk 2018). Elde edilen $p=.000$ değeri, $p<.001$ düzeyi için anlamlı bulunmuştur. Bunun üzerine gerçekleştirilen modifikasyonlar sonucu diğer uyum değerlerine de bakılmıştır. İlk olarak bakılan $\chi 2 / s d$ değeridir. Ki-kare istatistiğine 
göre örneklem büyüklüğünden daha az etkilendiği için $\chi 2 / s d$ oranı ölçüt olarak alınmıştır (Şimşek 2007). " $\chi 2$ " değerinin serbestlik derecesine bölünmesiyle elde edilen bu değer iki veya altındaki oranlar için mükemmel uyum demektir. Beş ve daha az ise kabul edilebilir bir değerdir (Munro 2005'ten aktaran Evci ve Aylar 2017; Şimşek 2007). DFA sonucu ölçeğin uyum indeksleri aşağıdaki tabloda sunulmuştur (Tablo 6).

Tablo 6.

Ölçeğin DFA Sonucu Uyum Değerleri

\begin{tabular}{cccc}
\hline Uyum İndeksleri & Ölçek Değerleri & Kabul Edilebilir Uyum & Mükemmel Uyum \\
\hline $\mathrm{X}^{2} / \mathrm{df}$ & 3,87 & $3 \leq 5$ & $2 \leq \mathrm{X} 2 / \mathrm{sd} \leq 3$ \\
\hline $\mathrm{CFI}$ & 0.93 & $.90 \leq \mathrm{CFI} \leq .95$ & $.95 \leq \mathrm{CFI} \leq 1.00$ \\
\hline $\mathrm{NFI}$ & 0.91 & $.90 \leq \mathrm{NFI} \leq .95$ & $.95 \leq \mathrm{NFI} \leq 1.00$ \\
\hline $\mathrm{FFI}$ & 0.93 & $.90 \leq \mathrm{IFI} \leq .95$ & $.95 \leq \mathrm{IFI} \leq 1.00$ \\
\hline $\mathrm{GFI}$ & 0.90 & $.90 \leq \mathrm{GFI} \leq .95$ & $.95 \leq \mathrm{GFI} \leq 1.00$ \\
\hline $\mathrm{RMSEA}$ & 0.78 & $.05 \leq \mathrm{RMSEA} \leq .10$ & $.00 \leq \mathrm{RMSEA} \leq .05$ \\
\hline SRMR & 0.72 & $.05 \leq \mathrm{SRMR} \leq .08$ & $.00 \leq \mathrm{SRMR} \leq .05$
\end{tabular}

Kaynak: (Çokluk, Şekercioğlu ve Büyüköztürk 2018; Erkorkmaz vd. 2013; Sümer 2000; Şimşek 2007; Tabachnick ve Fidell 2015)

Ölçeğin DFA sonucu uyum indekslerine bakıldığında karşılaması gereken sınıflandırmaları sağladığı görülmüştür. Ölçeğin yapısının kabul edilebilir bir uyum gösterdiği ve tek faktörlü yapısını doğruladığı tespit edilmiştir.

\section{Tartışma ve Sonuç}

Bu araştırma, eğlence amacına duyarlı medya okuryazarlığı ölçeğinin geliştirme, güvenirlik ve geçerlik çalışmalarından oluşmaktadır. Araştırmacı tarafından ölçek geliştirme süreci ihtiyaç analizi ile başlatılmıştır. Bu doğrultuda mevcut çalışmalar incelemeye alınmış, ülkemizde medya okuryazarlığı üzerine yapılan çalışmaların genellikle iletişim bilimleri, radyo, televizyon ve sinema, gazetecilik, halkla ilişkiler ve tanıtım vb. gibi bölümlerde yürütüldüğü tespit edilmiştir (Aydoğdu 2015; Baş 2021; Civelek 2021; Dumlu 2018; Edin 2019; Filiz 2020; Koç 2016; Özmen 2020; Sönmez 2021; Tanrıkulu 2019; Tan 2015; Ulusoy 2018; Yıldız 2017). Eğitim alanında yürütülen medya okuryazarlığı çalışmalarının ise genellikle üniversite öğrencileri ve öğretmenlere yönelik olduğu, ortaöğretimi kapsayan çalışmaların da medya okuryazarlığı becerilerine "genel" anlamda hitap ettiği görülmüştür (Aksoy 2021; Aksu 2019; Dolanbay 2018; Erdem 2018; Erişti ve Erdem 2017; İnan 2013; Görmez ve Kardaş 2017; Özel 2018; Sayın 2015; Tanrıkulu 2014). Ayrıca Aydemir (2019)'in üniversite öğrencilerine hitap eden, toplumsal cinsiyet teması ile sınırlandırılan ve yeni bir ölçek geliştirmeyi içeren çalışması da incelenmiştir. Incelenen araştırmaların bazılarında nitel veri ölçme araçları kullanılmıştır. Medya okuryazarlığı ölçme araçlarının özel olarak eğlence amacını ölçme amacı ile oluşturulmaması ve hedef kitleye uygunluk göstermemesi sebebi ile araştırmacı yeni bir ölçek geliştirme yoluna başvurmuştur.

Yeni bir ölçek geliştirme kararı sonrası, literatür taraması, öğretmen ve öğrencilerle görüşmeler, madde havuzu oluşturma, uzman görüşü alma ve uygulama öncesi ön deneme olmak üzere sırasıyla ölçek geliştirme aşamaları takip edilmiştir. Uzman görüşü ve ön deneme sonrası elde edilen 24 maddelik ölçek taslağı açımlayııı faktör analizi (AFA) için 404, doğrulayıcı faktör analizi (DFA) için ilk uygulama grubundan farklı olarak 234 kişiye uygulanmıştır. $5^{\prime}$ li likert tipi ile oluşturulan ölçek için alınabilecek en düşük puan 24 en yüksek puan ise 120 'dir. AFA ile elde edilen veriler sonucu ölçeğin tek boyutlu yapıda ve güvenilir olduğu ve DFA için gerekli şartları sağladığı tespit edilmiştir. DFA sonucunda ise ölçeğin tek faktörlü yapısı doğrulanmış ve kabul edilebilir uyum indekslerine sahip olduğu görülmüştür. Bu analizler doğrultusunda ölçeğin geçerli ve güvenilir olduğu sonucuna varılmıştır.

Dünyanın giderek dijitalleşmesi, iletişimin salt yüz yüze ile sınırlı kalmaması ve her türlü iletişim kodlarının her geçen gün daha da yoğun olmak üzere şekil ve içerik değiştirerek insanlara ulaşması 
okuryazarlık eğilimlerimizin ve buna bağı olarak becerilerimizin de değişmesi yönünde etkili olmaktadır. Üstelik dünyayı etkisi altında bırakan son yüzyılın en büyük dönüm noktalarından biri olan pandemi ile birlikte eğitim başta olmak üzere her alanda (eğlence, pazarlama, iş hayatı vb.) bu iletişim kodları ile ilişkimiz güçlenmiş ve bu kodların okuryazarlığına ilişkin sorumluluklarımız artmıştır. Bugün çocuklar için "eğlence" artık eğitimden ayrı düşünülemez duruma gelmiş, eğitim araçları da bu duruma yönelik şekil almıştır. Çocukları eğlence amacı ile ulaştıkları medyadan koparmak imkânsız hale geldiğinden, eğitmenler, aileler ve eğitim kurumları olarak yapılması gereken bu medya iletilerine dair farkındalık oluşturmak ve onları eğitim sürecine akıllıca dahil etmektir. Öğrenmenin kalıcılı̆ını ancak bu şekilde bir iş birliği ile hep birlikte öğrenme ve üretme sürecine dönüşecek "eğitim" sağlayabilecektir. Bu sebeple geliştirilen bu ölçeğin bu amaca hizmet etme yönünde alan yazına katkı sağlayacağı düşünülmektedir.

\section{Araştırma ve Yayın Etiği}

Bu çalışmada "Yükseköğretim Kurumları Bilimsel Araştırma ve Yayın Etiği Yönergesi" kapsamında uyulması belirtilen tüm kurallara uyulmuştur. Yönergenin ikinci bölümü olan "Bilimsel Araştırma ve Yayın Etiğine Aykırı Eylemler" başlığı altında belirtilen eylemlerden hiçbiri gerçekleştirilmemiştir.

\section{Etik Kurul İni}

Kurul adı $=$ Yıldız Teknik Üniversitesi

Karar tarihi $=05.08 .2021$

Belge sayı numarası $=$ E. 2108050416

\section{Uygulama izni}

Kurul adı = Millî Eğitim Bakanlığı

Karar tarihi $=01.09 .2021$

Belge sayı numarası= E17480297-605.01-30557829

\section{Yazarların Katkı Oranı}

1.yazarın katkı oranı $\% 60 ; 2$. Yazarın katkı oranı $\% 40$ 'tır.

\section{Çıkar Çatışması}

Bu çalışmada çıkar çatışması teşkil edebilecek bir durum veya ilişki bulunmamaktadır

\section{Kaynaklar}

Aksoy, N. (2021). Sosyal bilgiler öğretmen adaylarının medya okuryazarlığı algı düzeyleri ve görüşleri: Manisa Celal Bayar Üniversitesi örneği (Yayımlanmamış yüksek lisans tezi). Manisa Celal Bayar Üniversitesi Sosyal Bilimler Enstitüsü, Manisa.

Aksu, Y. (2019). Medya okuryazarlığı dersine ilişkin öğrenci tutumları ile öğretmen ve öğretmen adayı görüşlerinin değerlendirilmesi (Yayımlanmamış yüksek lisans tezi). Giresun Üniversitesi Sosyal Bilimler Enstitüsü, Giresun.

Aydemir, S. (2019). Toplumsal cinsiyet eşitliğine duyarlı medya okuryazarlığı eğitiminin öğretmen adaylarının toplumsal cinsiyet eşitliğine ilişkin tutumlarına etkisi (Yayımlanmamış doktora tezi). Gazi Üniversitesi Ĕgitim Bilimleri Enstitüsü, Ankara.

Baker, F. W. (2010). Media literacy: 21st century literacy skills. H. H. Jacobs (Ed.). In Curriculum 21: Essential Education for a Changing World (p.133-152). USA: ASCD.

Baş, M. N. (2021). Ergenlik çağındaki çocukların internet oyunları oynama alışkanlıklarının sosyal medya okuryazarlığı bağlamında incelenmesi (Yayımlanmamış yüksek lisans tezi). Selçuk Üniversitesi Sosyal Bilimler Enstitüsü, Konya.

Bayat, B. (2014). Uygulamalı sosyal bilim araştırmalarında ölçme, ölçekler ve "likert" ölçek kurma tekniği. Gazi Üniversitesi İktisadi ve Idari Bilimler Fakültesi Dergisi, 16(3), 1-24. 
Bazalgette, C. \& Buckingham, D. (2012). Literacy, media and multimodality: A critical response. Literacy, 47(2), 95-102.

Benson, J. \& Nasser, F. (1998). On the use of factor analysis as a research tool. Journal of Vocational Education Research, 23(1), 13-33.

Buckingham, D. (2003). Media education: literacy, learning and contemporary culture. Oxford: Polity Press.

Büyüköztürk, Ş. (2002). Faktör analizi: Temel kavramlar ve ölçek geliştirmede kullanımı. Kuram ve Uygulamada Eğitim Yönetimi, 32, 470-483.

Can, A. (2014). SPSS ile bilimsel araştırma sürecinde nicel veri analizi. Ankara: Pegem Akademi.

Child, D. (2006). Essentials of factor analysis (Third edition). New York: Continuum.

Civelek, Ş. (2021). Eleştirel medya okuryazarlığı bağlamında meslek liseleri gazetecilik alanı öğrencilerinin sosyal medyayı haber mecrası olarak kullanımlarının diğer öğrencilerle karşılaştırılması (Yayımlanmamış yüksek lisans tezi). Kocaeli Üniversitesi Sosyal Bilimler Enstitüsü, Kocaeli.

Çokluk, Ö., Şekercioğlu, G. ve Büyüköztürk, Ş. (2018). Sosyal bilimler için çok değişkenli istatistik: SPSS ve LiSREL uygulamaları. Pegem Akademi Yayıncılık, Ankara.

Diergarten, A. K., Möckel, T. Nieding, G. \& Ohler, P. (2017). The impact of media literacy on children's learning from films and hypermedia. Journal of Applied Developmental Psychology, 48, 33-41.

Dolanbay, H. (2018). Sosyal Bilgiler öğretmen adaylarına yönelik medya okuryazarlığı eğitimi modeli (Yayımlanmamış doktora tezi). Marmara Üniversitesi Ĕgitim Bilimleri Enstitüsü, İstanbul.

Dumlu, A. (2018). Katılımcı yurttaşılık bilincinin geliştirilmesi bağlamında AB ülkelerinde medya okuryazarlığı (Yayımlanmamış yüksek lisans tezi). Akdeniz Üniversitesi Sosyal Bilimler Enstitüsü, Antalya.

Edin, P. G. (2019). Avrupa mevzuatı ile karşılaştırmalı olarak Türkiye'de medya okuryazarlığı ve karşılaşılan sorunlar (Yayımlanmamış yüksek lisans tezi). Gazi Üniversitesi Sosyal Bilimler Enstitüsü, Ankara.

Erdem, C. (2018). Öğretmen adayları için medya okuryazarlığı dersi öğretim programı tasarısı (Yayımlanmamış doktora tezi). Anadolu Üniversitesi Eğitim Bilimleri Enstitüsü, Eskişehir.

Erişti, B. ve Erdem, C. (2017). Development of a media literacy skills scale. Contemporary Educational Technology, 8(39), 249-267.

Erkorkmaz, Ü., Etikan, i., Demir, O., Özdamar, K. ve Sanisoğlu, Y. (2013). Doğrulayıcı faktör analizi ve uyum indeksleri. Turkiye Klinikleri Journal of Medical Science, 33(1), 210-23.

Erkuş, A. (2007). Ölçek geliştirme ve uyarlama çalışmalarında karşılaşılan sorunlar. Türk Psikoloji Bülteni, 13(40), 17-25.

Evci, N. ve Aylar, F. (2017). Derleme: Ölçek geliştirme çalışmalarında doğrulayıcı faktör analizi kullanımı. Sosyal Bilimler Dergisi, 4(10), 389-412.

Facione, P. A. (1990). Critical thinking: A statement of expert consensus for purposes of educational assessment and instruction: The Delphi Report. Millbrae CA: California Academic Press.

Filiz, H. (2020). Medya okuryazarlı̆̆ı ve aile değerleri bağlamında televizyonun Türk aile yapısına etkisi (Yayımlanmamış Doktora Tezi). Marmara Üniversitesi Sosyal Bilimler Enstitüsü, İstanbul.

Freire, P. \& Macedo, D. P. (1998). Okuryazarlık: Sözcükleri ve dünyayı okuma. (S. Ayhan, Çev.). Ankara: Imge Kitabevi.

Gaines, E. (2010). Media Literacy and semiotics. New York: Palgrave Macmillan.

Giroux, H. A. (1991). Postmodernism, feminism, and cultural politics: redrawing educational boundaries. New York: State University of New York Press.

Görgülü Aydoğdu, A. (2015). Eleştirel farkındalık yaratmada yeni medya okuryazarlığı ve yeni medya bilinci üzerine bir inceleme (Yayımlanmamış doktora tezi). Gazi Üniversitesi Sosyal Bilimler Enstitüsü, Ankara.

Görmez, E. (2014). Ortaokul öğrencilerinin medya okuryazarlığı düzeyleri (Yayımlanmamış doktora tezi). Atatürk Üniversitesi Eğitim Bilimleri Enstitüsü, Erzurum.

Görmez, E. ve Kardaş, M. N. (2017). Etkili medya eğitimi uygulamaları için bir ölçek geliştirme çalıştırması. Turkish Studies, 12(4), 167-186. 
Hobbs, R. (1998a). Teaching with and about film and television. Journal of Management Development, 17(4), 259-272.

Hobbs, R. (1998b). The Simpsons meet Mark Twain: Analyzing popular media texts in the classroom. The English Journal, 87(1), 49-51.

Hobbs, R. (2005). The state of media literacy education. Journal of Communication, 55(4), 865-871.

Hobbs, R. (2013). Improvization and strategic risk-taking in informal learning with digital media literacy. Learning, Media and Technology, 38(2), 182-197.

Hobbs, R. (2018). Media education, copyrigt and fair use. R. Hobbs (Ed). In The Routledge Companion to Media Education, Copyright, and Fair Use (p.3-21). New York: Routledge.

İnan, T. (2013). Medya okuryazarlığı sürecinde medya, çocuk ve ebeveyn ilişkisi: ortaokul öğrencilerinin ve ebeveynlerinin televizyon ve internet kullanımlarına ilişkin tutum ve davranışlarının incelenmesi (Yayımlanmamış Doktora Tezi). Dumlupınar Üniversitesi Eğitim Bilimleri Enstitüsü, Kütahya.

Jenkins, H. (2006). Convergence culture: Where old and new media collide. US: New York University Press.

Karakoç, F. Y. ve Dönmez, L. (2014). Ölçek geliştirme çalışmalarında temel ilkeler. Tıp Eğitimi Dünyası, 40, 39-49.

Kellner, D. \& Share, J. (2005). Toward critical media literacy: Core concepts, debates, organizations and policy. In Discourse: Studies in the Cultural Politics of Education, 26(3): 369-386.

Koç, E. (2016). Türkiye'deki medya okuryazarlığı eğitimi için bir uygulama önerisi (Yayımlanmamış doktora tezi). Maltepe Üniversitesi Sosyal Bilimler Enstitüsü, İstanbul.

Koçak, D., Çokluk, Ö. ve Kayri, M. (2016). Faktör sayısının belirlenmesinde MAP testi, paralel analiz, k1 ve yamaç birikinti grafiği yöntemlerinin karşılaştırılması. YYÜ Eğitim Fakültesi Dergisi (YYU Journal Of Education Faculty), 13(1), 330-359.

Lawshe, C. H. (1975). A quantitative approach to content validity. Personel Psychology, 28(4), 563-575.

Meibauer, B. K. (2013). Introduction: New perspectives in children's film studies. Journal of Educational Media, Memory \& Society, 5(2), 39-44.

Özel, A. (2018). Sosyal bilgiler öğretmen adaylarının medya okuryazarlığı algılarının incelenmesi (Yayımlanmamış doktora tezi). Dumlupınar Üniversitesi Eğitim Bilimleri Enstitüsü, Kütahya.

Özmen, C. (2020). Türkiye'de medya okuryazarlığı ve geleceği (Yayımlanmamış yüksek lisans tezi). Üsküdar Üniversitesi Sosyal Bilimler Enstitüsü, İstanbul.

Seçer, i. (2015). SPSS ve LISREL ile pratik veri analizi. Ankara: Anı Yayıncılık

Sönmez, G. (2021). Türkiye'de kamunun halkla ilişkiler uygulamaları: Medya okuryazarlığı örneği (Yayımlanmamış doktora tezi). Marmara Üniversitesi Sosyal Bilimler Enstitüsü, İstanbul.

Sümer, N. (2000). Yapısal eşitlik modelleri: Temel kavramlar ve örnek uygulamalar. Türk Psikoloji Yazıları, 3(6), 49-74.

Stuckey, H. \& Kring, K. (2007). Critical media literacy and popular film: Experiences of teaching and learning in a graduate class. New Directions For Adult And Continuing Education, 15, 25-33.

Şimşek, Ö. F. (2007). Yapısal eşitlik modellemesine giriş, temel ilkeler ve LiSREL uygulamaları. Ankara: Ekinoks Yayınları.

Tabachnick, B. G. \& Fidell, L. (2015). Çok değişkenli istatistiklerin kullanımı. (M. Baloğlu, Çev. ed.). Ankara: Nobel Yayıncilık.

Tan, O. (2015). Medya okuryazarlığı eğitimi: Öğrenci, öğretmen, aile bağlamında örnek bir araştırma (Yayımlanmamış doktora tezi). Akdeniz Üniversitesi Sosyal Bilimler Enstitüsü, Antalya.

Tanrıkulu, F. (2014). Medya okuryazarlığı bağlamında çocuk dergileriyle zenginleştirilmiş Türkçe dersinin etkililiği: Bir eylem araştırması (Yayımlanmamış doktora tezi). Çanakkale On Sekiz Mart Üniversitesi Eğitim Bilimleri Enstitüsü, Çanakkale.

Tanrıkulu, S. (2019). Medya okuryazarlığı ve medya okuryazarlığı dersinin öğrencilere katkısı üzerine bir araştırma (Yayımlanmamış yüksek lisans tezi). Selçuk Üniversitesi Sosyal Bilimler Enstitüsü, Konya.

Thoman, E. (1995). Operational definition of media literacy. Los Angeles: Center for Media Literacy. 
Thoman, E. \& Jolls, T. (2004). Media literacy: A national priority for a changing world. American Behavioral Scientist, 48(1), 18-29.

Thompson, B. (2004). Exploratory and confirmatory factor analysis: Understanding concepts and applications. Washington: American Psychological Association.

Thompson, J. B. (2008). Medya ve modernite. (S. Öztürk, Çev.). İstanbul: Kırmızı Yayınları.

Ulusoy, A. (2018). Dijital medya okuryazarlığı, gereksinimler ve yenilikçi uygulamalar üzerine bir inceleme (Yayımlanmamış doktora tezi). Erciyes Üniversitesi Sosyal Bilimler Enstitüsü, Kayseri.

Wan, G. \& Gut, D. M. (2008). Media use by Chinese and U.S. secondary students: Implications for media literacy education. Theory Into Practice, 47, 178-185.

Watkins, M. W. (2021). A step-by-step guide to exploratory factor analysis with SPSS. New York: Routledge.

Whitley, D. (2013). Learning with Disney: Children's animation and the politics of innocence. Journal of Educational Media, Memory \& Society, 5(2), 75-91.

Yıldız, A. (2017). Ebeveynlerde medya okuryazarlığı yeterliliği: Ankara saha araştırması (Yayımlanmamış yüksek lisans tezi). Gazi Üniversitesi Sosyal Bilimler Enstitüsü, Ankara.

\section{Extended Abstract}

\section{Introduction}

The literacy trends of the 21st century is shifting towards areas such as media literacy and digital literacy with the development of technology. Rapid changes in science and technology show that people need to adapt to scientific-technological developments, social integration and interaction and plan their education systems accordingly. The new world continues to evolve, becoming stronger than before and requiring more cognitive skills for new meaning codes. For this reason, the new communication codes of the digital universe require developing media literacy skills, performing the critical thinking process at every stage of learning, and using them in education with different activities by interacting between life and school.

\section{Method}

This study aims to develop a scale that also targets critical thinking about the entertainment media tools that secondary school students follow, spend a lot of time and are exposed to in their daily lives. The need to develop this scale has arisen because the existing scales in the literature are not intended for this limited purpose and do not meet the target audience in practice. The scale developed in this context was created in accordance with the five-point Likert structure. Accordingly, the items in the scale were graded as " $1=$ Strongly Disagree, 2=Disagree, 3= Undecided, 4=Agree, 5=Strongly Agree". The strength of Likert scaling is that each proposition in the scale, on the one hand, contributes to the emergence/determination of the internal feature to be measured, on the other hand, it also allows obtaining a total score for the internal feature that is desired to be measured (Bayat 2014: 15).

\section{Result and Discussion}

This research consists of the development, reliability and validity studies of the media literacy scale sensitive to entertainment purposes. The scale development process was initiated by the researchers with needs analysis. In this direction, existing studies were examined. Findings show that in Turkey, media literacy studies were carried out mostly in the departments like communication sciences, radio, television and cinema, journalism (Aydoğdu 2015; Baş 2021; Civelek 2021; Dumlu 2018; Edin 2019; Filiz 2020; Koç 2016; Özmen 2020; Sönmez 2021; Tanrıkulu 2019; Tan 2015; Ulusoy 2018; Yıldız 2017). It was observed that media literacy studies carried out in the field of education are generally aimed at university students and teachers, and studies covering secondary education also address media literacy skills in a "general" sense (Aksoy 2021; Aksu 2019; Aydemir 2019; Özel 2018; Dolanbay 2018; Erdem 2018; Erişti ve Erdem 2017; Görmez ve Kardaş 2017; İnan 2013; Sayın 2015; Tanrıkulu 2014). Qualitative data measurement tools were used in some of the studies examined. The researchers resorted to developing a new scale because the media literacy measurement tools were 
not created specifically to measure the purpose of entertainment and were not suitable for the target audience.

After the decision to develop a new scale the stages of scale development were followed including literature review; interviews with teachers and students; creating an item pool; getting expert opinion; and pre-testing before the application. The 24-item draft scale, which was obtained after expert opinion and pre-testing, was applied to 404 participants for exploratory factor analysis (EFA) and to 234 people for confirmatory factor analysis (CFA), different from the first application group. The lowest score that can be obtained for the scale created with a 5-point Likert type is 24 and the highest score is 120 . As a result of the data obtained with EFA, it was determined that the scale was unidimensional and reliable and provided the necessary conditions for CFA. As a result of CFA, the single-factor structure of the scale was confirmed and it was seen that it had acceptable fit indices. The results of these analyses showed that the scale was valid and reliable.

The increasing digitalization of the world, the fact that communication is not limited to faceto-face mode, and that all kinds of communication codes reach people by changing their form and content, becoming more and more intense with each passing day, are effective in changing our literacy tendencies and accordingly our skills. Moreover, with the pandemic, one of the biggest turning points of the last century that left the world under its influence, our relationship with these communication codes has strengthened and our responsibilities regarding the literacy of these codes have increased in every field (entertainment, marketing, business life, etc.), especially in education. Today, "entertainment" for children has become inseparable from education and educational tools have adjusted themselves to this situation. Since it has become impossible to detach children from the media they reach for entertainment purposes, what needs to be done as educators, families and educational institutions is to raise awareness of these media messages and to involve them wisely in the education process. In this way, "education", which will turn into a learning and production process together with cooperation, will be able to provide permanence, only. For this reason, it is thought that this scale will contribute to the literature in order to serve this purpose.

\section{Ek-1. Eğlence Amacına Duyarlı Medya Okuryazarlığı Ölçeği}

\begin{tabular}{|c|c|c|c|c|c|c|}
\hline & & 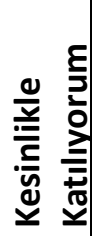 & 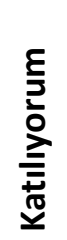 & 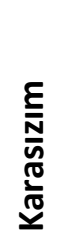 & 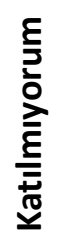 & 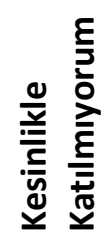 \\
\hline 1 & Medya içeriklerindeki bilgilerin doğruluğunu sorgularım. & & & & & \\
\hline 2 & Medya içeriklerindeki bilgilerin güvenirliğini sorgularım. & & & & & \\
\hline 3 & $\begin{array}{l}\text { Medya araçlarında karşılaştığım içerikleri başka } \\
\text { kaynaklardan doğrulama ihtiyacı duyarım. }\end{array}$ & & & & & \\
\hline 4 & $\begin{array}{l}\text { Amacıma uygun, farklı türde medya araçlarını (televizyon, } \\
\text { sinema, sosyal medya, dergi vb.) takip ederim. }\end{array}$ & & & & & \\
\hline 5 & $\begin{array}{l}\text { Eğlence amaçlı takip ettiğim medya araçlarının (film, dizi, } \\
\text { video vb.) içerik (konu, karakterler, dönem, iletiler vb.) } \\
\text { özellikleri üzerine düşünürüm. }\end{array}$ & & & & & \\
\hline 6 & $\begin{array}{l}\text { Eğlence amaçlı takip ettiğim medya araçlarında (film, dizi, } \\
\text { video vb.) içeriği desteklemek amacı ile kullanılan teknik } \\
\text { özellikler (ses, görüntü, efekt vb.) üzerine düşünürüm. }\end{array}$ & & & & & \\
\hline 7 & $\begin{array}{l}\text { Eğlence amaçlı takip ettiğim medya araçlarındaki (film, dizi, } \\
\text { video vb.) karakterlerin (kahramanların) özellikleri (fiziki, } \\
\text { psikolojik vb.) dikkatimi çeker. }\end{array}$ & & & & & \\
\hline
\end{tabular}




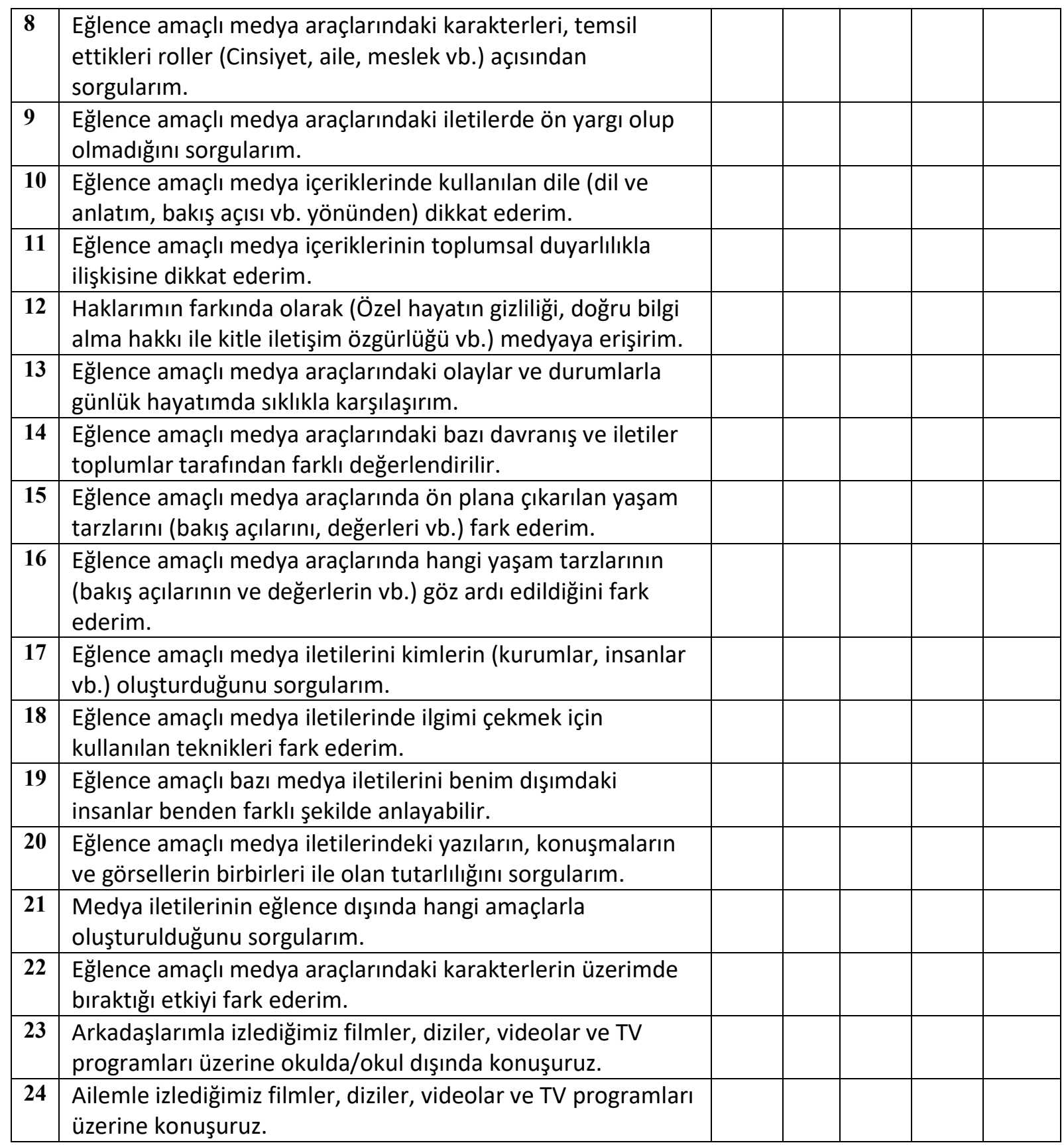

